\title{
Adipose tissue mature stem cells in skin healing: a controlled randomized study
}

\author{
Uso de células-tronco adultas de tecido adiposo na cicatrização da pele: estudo \\ controlado, randomizado
}

Pedro Djacir Escobar

MARTINS $^{1}$

Carlos Oscar Uebel ${ }^{2}$

Denise Cantarelli

MACHADO $^{3}$

JefFErson Braga da Silva ${ }^{4}$

Study conducted at the Plastic Surgery Service of Hospital São Lucas of Pontifícia Universidade Católica do Rio Grande do Sul, Porto Alegre, RS, Brazil.

Submitted to SGP (Sistema de Gestão de Publicações/Manager Publications System) of RBCP (Revista Brasileira de Cirurgia Plástica/Brazilian Journal of Plastic Surgery).

Received: May 28, 2011 Accepted: August 19, 2011

\begin{abstract}
Background: The differences between fetal and adult scars suggest the possibility of manipulating skin scarring outcomes. This study aimed to assess whether the use of adult stem cells from adipose tissue is beneficial to skin healing. Methods: This was a randomized controlled study for which 18 patients were selected based on inclusion and exclusion criteria. The adult stem cells used were autologous and were extracted from infraumbilical adipose tissue prior to abdominoplasty. These cells were implanted into the surgical wound dermis in the suprapubic region before skin synthesis. The results were assessed blindly based on the Draaijers scale by three physicians and by the patients themselves in a self-assessment. Photometric assessment by digital photography was also performed. Results: Among the 18 operated patients, considering the surgical result, $17(94.4 \%)$ had excellent or good results and one (5.5\%) had wound dehiscence, which was considered a bad result. Considering skin healing in the searched area, there was no statistically significant difference in the photometric evaluation; in both the self-assessment by the patients and the physicians' assessment, the results were significantly in favor of intervention with stem cells $(\mathrm{P}=0.12$ and $\mathrm{P}=0.003$, respectively). Consideration of all assessments (physicians, patients and photometric) found a statistically significant difference in favor of the implantation of adult stem cells from adipose tissue $(\mathrm{P}<0.001)$. Conclusions: Skin healing results after implantation of adult stem cells derived from adipose tissue were satisfactory.
\end{abstract}

Keywords: Stem cells. Wound healing. Abdomen/surgery.

\section{RESUMO}

Introdução: Fatores que diferenciam a cicatrização fetal e a do adulto instigam a possibilidade de manipulação das soluções de continuidade da pele. Este estudo teve como objetivo avaliar se o uso de células-tronco adultas do tecido adiposo é benéfico à cicatrização da pele. Método: Estudo controlado, randomizado, para o qual foram selecionadas 18 pacientes, considerando-se critérios de inclusão e exclusão. As células-tronco adultas utilizadas eram autólogas, extraídas do tecido adiposo da região infraumbilical, precedendo a realização da abdominoplastia. Essas células, antes da síntese da pele, foram implantadas na derme da ferida operatória, na região suprapúbica. A avaliação dos resultados foi realizada com base na escala de Draaijers, por três avaliadores médicos cegados, e pelas próprias pacientes, por autoavaliação. Foi realizada, também, avaliação fotométrica por fotografia digital. Resultados: Dentre as 18 pacientes operadas, sob o ponto de vista cirúrgico, $17(94,4 \%)$ apresentaram resultados excelentes ou bons e uma $(5,5 \%)$ apresentou deiscência de sutura, considerado mau resultado. Quanto à cicatrização da pele na área pesquisada, à avaliação fotométrica, não houve diferença estatisticamente significante; à autoavaliação pelas pacientes, os resultados atingiram nível de significância a favor da intervenção com células-tronco $(\mathrm{P}=0,12)$; e à avaliação pelos médicos, foi atingido nível de significância a favor da intervenção por células-tronco $(\mathrm{P}=0,003)$. Considerando-se todas as avaliações realizadas (médicos, pacientes e fotométrica), foi encontrada diferença estatisticamente significante favorável ao implante de células-tronco adultas do tecido adipose $(\mathrm{P}<0,001)$. Conclusões: Os resultados da cicatrização da pele, após implante de células-tronco adultas derivadas de tecido adiposo, foram satisfatórios.

Descritores: Células-tronco. Cicatrização. Abdome/cirurgia.

1. Ph.D. in Surgery from Pontifícia Universidade Católica do Rio Grande do Sul (PUCRS), head of the Plastic Surgery Service of Hospital São Lucas da PUCRS, full member of the Brazilian Society of Plastic Surgery (SBCP), Porto Alegre, RS, Brazil.

2. Ph.D. in Surgery from PUCRS, full member of SBCP, preceptor of the Plastic Surgery Service of Hospital São Lucas of PUCRS, Porto Alegre, RS, Brazil.

3. Ph.D. in Cell Immunology from University of Sheffield, United Kingdom, coordinator of the Cell Therapy Center of the Institute of Biomedical Research of PUCRS, Porto Alegre, RS, Brazil.

4. Full professor, former president of the Brazilian Society of Reconstructive Microsurgery, former president of the Brazilian Society of Hand Surgery, Porto Alegre, RS, Brazil. 


\section{INTRODUCTION}

Since the Egyptian age, surgeons have been concerned about wounds and their healing, as evidenced in the papyrus of Edwin S. Smith ${ }^{1}$. Closing the surgical wound is a basic condition for surgical success.

It is essential for the physician to have knowledge of the healing process in order to handle the tissues correctly and obtain an optimal outcome. Healing is divided into inflammatory, proliferative, and maturation stages ${ }^{2,3}$. The inflammatory or reactive stage lasts about four days and begins at the moment the injury occurs. The proliferative or regenerative stage begins on the fourth day post-injury and lasts about ten days. The last stage, maturation, is the longest and may last from the eighth day to the sixth month or more. In this stage, the scar tension increases quickly between one week and six weeks post-injury and reaches its maturity plateau after about one year of tissue remodeling.

Several factors such as infection, local tissue ischemia, diabetes mellitus, radiation, malnutrition, exogenous drugs, and deficiency of minerals and vitamins ${ }^{3}$ may interfere with the healing process and its progression in a very complex set of events.

The scar may be considered adequate, inadequate, or proliferative. These results are determined by the balance between collagen synthesis and degradation. If this balance tilts in either direction, the result will not be satisfactory. In chronic wounds, collagen degradation is greater than its synthesis, whereas in proliferative, hypertrophic, or keloid scars, the opposite occurs, i.e., collagen deposition exceeds its degradation ${ }^{3}$.

Studies of human fetuses operated on in utero revealed that scars were minimal or unnoticeable after birth ${ }^{4}$. Lin et al. ${ }^{5}$ concluded that fetal fibroblasts remained true to their phenotype even when transplanted into adults. This fetal healing process takes place in the absence of inflammation, resulting in a non-apparent scar. According to Estes et al. ${ }^{6}$, fibroblasts in fetal wounds do not develop to an activated state (myofibroblasts) until a late stage of pregnancy. Bullard et al. ${ }^{7}$ demonstrated that dermal fibroblasts have significantly more interstitial collagenase in fetal wounds than in those of adults. There is evidence that less inflammation and reduced collagen accumulation occur in fetal healing compared to the adult process. These facts suggest the possibility of manipulating skin scarring in adults with the aim of limiting the intensity of the inflammatory process and thus producing a better result for the scar.

Plastic surgeons in particular have directed their attention to skin healing. In their surgeries, they seek to conceal the scars by placing them according to the force lines of the skin in areas where they will not be visible or will be only minimally noticeable. When the scars are located in constantly exposed areas, as in the face, they use or conduct concealing therapeutic and cosmetic measures to make the scars less noticeable ${ }^{3,8-11}$.

Progress in studies of cellular and molecular biology may have a large impact on understanding the healing process and its clinical applications. Research using stem cells is advancing the understanding of how damaged cells are replaced by healthy cells in adult organisms ${ }^{12,13}$. This is an area of intense academic and applied research. The use of stem cells to treat diseases, known as regenerative medicine ${ }^{13}$, has greatly advanced. Stem cells are fundamental not only to coordinate the formation of organs from the embryonic to the adult stage but also for their role in regeneration and tissue repair.

Although several criteria for defining stem cells have been proposed, in short, they should be undifferentiated cells capable of proliferation, self-renewal, production of numerous functionally differentiated cells and tissue regeneration after an injury ${ }^{14}$. In consideration of ethical and legal issues, researchers pursuing therapeutic applications have conducted their studies with stem cells, especially those derived from bone marrow stroma ${ }^{15-18}$. More recent studies have shown that this cell population can also be isolated from adipose tissue ${ }^{19-22}$ collected by means of liposuction ${ }^{23,24}$. Some authors prefer not to use the term stem cells, referring to this adipose tissue material as processed lipo-aspirate (PLA) cells or adipose-derived adult stem cells (ADAS) ${ }^{20,21,25,26}$.

Clinical research using autologous stem cells extracted from adipose tissue is encouraged as the cells are easy to obtain. This study aims to assess the effects of these cells on human skin healing.

\section{METHODS}

\section{Ethical Aspects}

This study was approved on 11/24/2005, as Protocol No 05/02789, by the Ethics Committee of Hospital São Lucas of Pontifícia Universidade Católica do Rio Grande do Sul (PUCRS - Porto Alegre, RS).

All patients who participated in this study signed an informed consent form.

\section{Procedures}

Cells obtained exclusively from autologous adipose tissue were used in patients in this study. Its implementation did not alter the surgical sequence or significantly increase the duration of the proposed procedure.

The collection of adipose tissue was performed in a maximum period of 5 minutes prior to abdominoplasty. The implantation of adult stem cells from adipose tissue was of similar duration. The separation of these cells, which was of similar duration as the abdominoplasty, was performed at the Cell Therapy Center of the Institute of Biomedical Research of PUCRS simultaneously with the surgery. 
The inclusion criteria considered were patients in the Plastic Surgery Service of Hospital São Lucas of PUCRS, indications for abdominoplasty, white skin, female gender, age between 30 and 45 years, already having children, and having no stretch marks in the supraumbilical region.

The exclusion criteria were smoking, history of keloids or hypertrophic scarring, diabetes mellitus, any skin or connective tissue disease, previous supraumbilical scar, prolonged use of corticosteroids, previous chemotherapy or radiotherapy, weight loss post-obesity, infection, hematoma, seroma or dehiscence during the abdominoplasty postoperative period and patient withdrawal during the course of the study.

All patients who participated in this study were operated on by the same surgeon, and the same surgical technique, which consisted of liposuction in the infraumbilical region followed by abdominoplasty, was performed in all of them ${ }^{27,28}$. These two procedures are performed in the same surgery, facilitating the production of the scar as the object of this study and the acquisition of the adipose tissue from which adult stem cells were taken.

Prior to abdominoplasty, $30 \mathrm{ml}$ of adipose tissue was collected by liposuction from the infraumbilical region where there is a major concentration of adult stem cells ${ }^{29}$. Liposuction was performed with a 50-ml disposable syringe and a cannula with a caliber of $4 \mathrm{~mm}$ and length of $25 \mathrm{~cm}$. In order to avoid any change in the adipose tissue, this procedure was performed without infiltration at the site (dry procedure ${ }^{24}$. The adipose tissue was transported, in its own syringe and under sterile conditions, to the Cellular Therapy Center of the Institute of Biomedical Research of PUCRS in order to carry out the extraction of adult stem cells while the surgery was performed (Figure 1).

\section{Surgical Technique}

All patients were operated on under epidural anesthesia with puncture in the L3-L4 epidural space and injection of $150 \mathrm{mg}$ of ropivacaine hydrochloride $0.75 \%$ and $100 \mathrm{mg}$ of fentanyl citrate. In the transoperative period, the patient was sedated with midazolam $15 \mathrm{mg}$, intravenously, in divided doses.

The same surgical sequence was followed in the abdominoplasty for all cases: prior resection, in a single block, of the skin flap and subcutaneous cell tissue from the infraumbilical region in the area from the umbilical scar to the pubic region located between the two anterosuperior iliac spines ${ }^{27,28}$ (Figure 2). Then, juxta-aponeurotic detachment of the supraumbilical dermal-adipose flap to the level of the ribs and xiphoid process was performed. Next, the musculoaponeurotic wall of the abdomen was repositioned by plication with discontinuous stitches of 2.0 monofilament nylon $\left(\right.$ Ethicon $\left.^{\circledR}\right)$. The umbilical scar was fixed with 4.0 monofilament nylon sutures $\left(\right.$ Ethicon $\left.^{\circledR}\right)$ in the musculoaponeurotic wall and sutured with the same thread to the skin of the supraumbilical dermal-adipose flap that had been pulled up to its new position at the pubic edge of the surgical incision. To complete the abdominoplasty, the closure of the surgical wound upper and lower edges was performed at all levels. This synthesis resulted in the abdominoplasty scar in which the research with adult stem cells from adipose tissue was conducted (Figure 3).

For the skin closure, the same procedures were always followed, i.e., 4.0 monofilament nylon thread $\left(\right.$ Ethicon $\left.^{\circledR}\right)$ was used for the subdermal layer and 3.0 monofilament nylon thread (Ethicon ${ }^{\circledR}$ ) for the subcutaneous cell tissue and the intradermal sutures.

In all patients, a $1 / 4$ suction drain (Drenoplass ${ }^{\circledR}$ ) was placed by inferior counter-incision in the pubic region. The purpose of this drain was to prevent fluid accumulation that could stretch the skin and change the tension of the suture lines in the studied region.

\section{Adult Stem Cell Collection from Adipose Tissue}

The extraction of adult stem cells from adipose tissue was performed at the Cell Therapy Center of the Institute

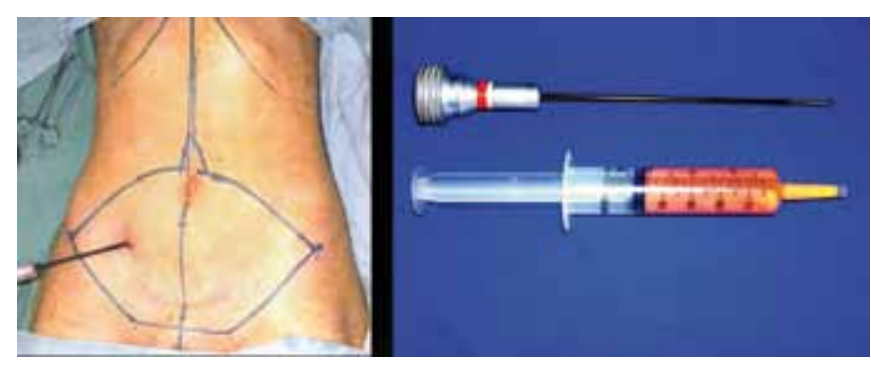

Figure 1 - Liposuction with syringe. In A, demarcation of the skin flap and subcutaneous cell tissue to be resected. In $\boldsymbol{B}$, cannula for liposuction and syringe with adipose tissue.

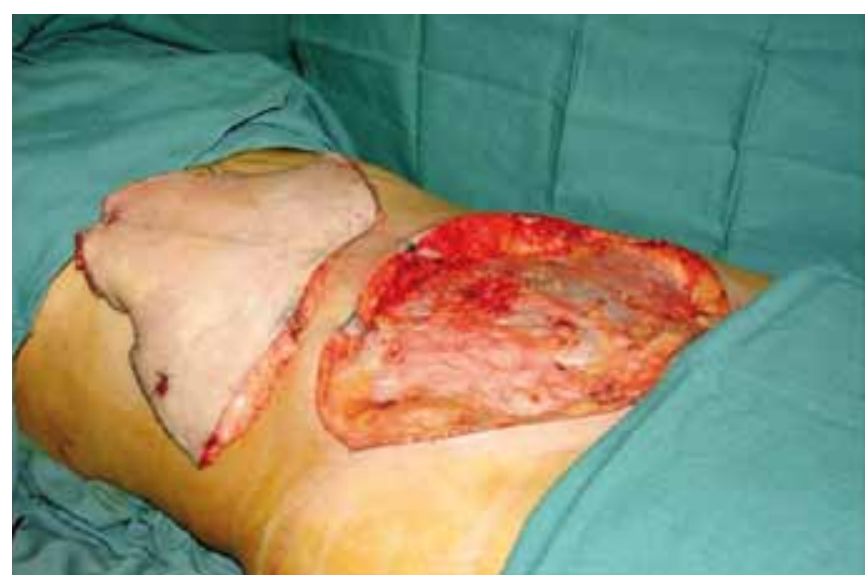

Figure 2 - Prior resection: infraumbilical flap resected in a single block prior to supraumbilical detachment. 


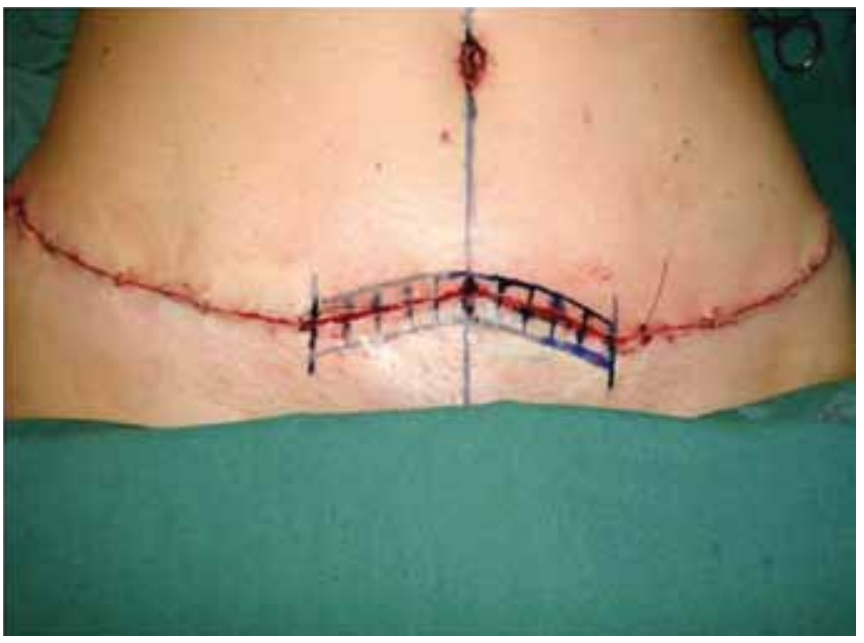

Figure 3 - Suprapubic wound: region of use of adult stem cells from adipose tissue in both edges of the surgical wound, randomized to the side of the midline.

of Biomedical Research of PUCRS as follows: $20 \mathrm{ml}$ of adipose tissue was divided between two tubes and washed with $40 \mathrm{ml}$ of Dulbecco's Phosphate-Buffered Saline (DPBS; Invitrogen Corp., Carlsbad, CA, USA) containing $2 \%(\mathrm{v} / \mathrm{v})$ of fetal bovine serum (FBS; Invitrogen Corp., Carlsbad, CA, USA) for red blood cell collection. The suspension was centrifuged at $450 \times g$ for five minutes. The adipose tissue was transferred to a new tube to which $0.015 \%(\mathrm{w} / \mathrm{v})$ of collagenase (Sigma Corp., St. Louis, MO, USA) diluted in DPBS in a total of $50 \mathrm{ml}$ was added. The tube was placed in an orbital shaker and incubated at $37^{\circ} \mathrm{C}$ for 45 minutes until the tissue was completely dissociated. The collagenase was inactivated with the culture medium Dulbecco's modified Eagle's medium (DMEM - Invitrogen Corp. Carlsbad, CA, USA) containing $10 \%(\mathrm{v} / \mathrm{v}) \mathrm{FBS}$, and the solution was divided between two tubes. The cells were centrifuged at $1,200 \times g$ for 10 minutes, and the supernatant was discarded. The cells were resuspended in $10 \mathrm{ml}$ of DPBS containing $10 \%$ (v/v) FBS and centrifuged again for washing. Then, the total number of cells was quantified using a hemocytometer. The cells were resuspended in saline to a density of $5 \times 10^{8}$ cells per $\mathrm{ml}$ for infiltration of the scar.

Flow cytometry was performed with the following antibodies: CD73, CD105, and CD117. The samples were analyzed in a FACSCalibur flow cytometer (Becton Dickinson Immunocytometry Systems, San Jose, CA, USA). An aliquot of 100 $\mu \mathrm{l}$ of the suspension of adult stem cells from adipose tissue was used for characterization of the cell populations. Twenty microliters of each antibody was added, and the solution was incubated at room temperature for 30 minutes in the dark. The sample was centrifuged at $200 \times g$ for 5 minutes, and the supernatant was discarded. The sample was washed with $2 \mathrm{ml}$ of PBS (with $0.1 \%$ sodium azide and $1 \%$ FBS) by centrifugation at $200 \times g$ for 5 minutes. The supernatant was discarded and the cells were resuspended in $500 \mu 1$ of PBS.

Use of Adult Stem Cells from Adipose Tissue on the Scar

To carry out this research, the segment located in the suprapubic region in the location of the abdominoplasty incision was selected and marked $5 \mathrm{~cm}$ to each side of midline (Figure 3). One side of each incision was randomly chosen for implantation of adult stem cells from adipose tissue, and the side selected was not known to the patients or the observers.

Before the skin closure, adult stem cells from adipose tissue suspended in saline were implanted in the surgical wound dermis. Prior to beginning the portion of the study with the selected patients, the volume required to reach the area of $1 \mathrm{~cm}^{2}$ of the skin was calculated by injecting methylene blue into the dermis. It was found that each $0.5 \mathrm{ml}$ injected covers $1 \mathrm{~cm}^{2}$ of the skin (Figures 4 and 5).

On the randomly chosen side, $5 \mathrm{ml}$ of saline containing adult stem cells from adipose tissue at a density of $5 \times 10^{8}$ per $\mathrm{ml}$ was injected into both edges of the surgical wound ${ }^{18}$. In the contralateral side, which served as a control, an identical volume of saline was injected. It was thus possible to compare the healing process with and without implantation of adult stem cells from adipose tissue in the same patient.

\section{Healing Assessment}

Research in the field of healing is still in its initial stages. In 1997, Morris et al. ${ }^{30}$ described a study using rabbits' ears to compare the treatment of hypertrophic scars with triamcinolone or saline solution.

Historically, human healing has been assessed by clinical studies. For this reason, a system for scar assessment in a common medical language is necessary. The Vancouver scale has had great acceptance and is widely used for burns ${ }^{31-34}$. In 1998, Beausang et al. ${ }^{35}$ expanded this scale to make it more comprehensive for assessment of linear scars after surgery or trauma. As these two scales did not include a self-assessment component, Draaijers et al. ${ }^{36}$ created a scale that relies on the patient's and observer's assessments.

In addition to these scales, morphometric analysis by digital photography has been considered an objective method for documentation and assessment of scars ${ }^{37}$.

The scars were assessed in this study by the following methods:

1. Patient/observer scales (Draaijers et al. ${ }^{36}$ ) - consists of two numeric scales validated and tested in relation to the Vancouver scale ${ }^{31-34}$. The observer's scale contains 5 assessment items: vascularization, pigmentation, elasticity, thickness, and relief. The patient's scale contains six assessment items: color, elasticity, thickness, relief, itching, and pain. Each assessment item receives a score 


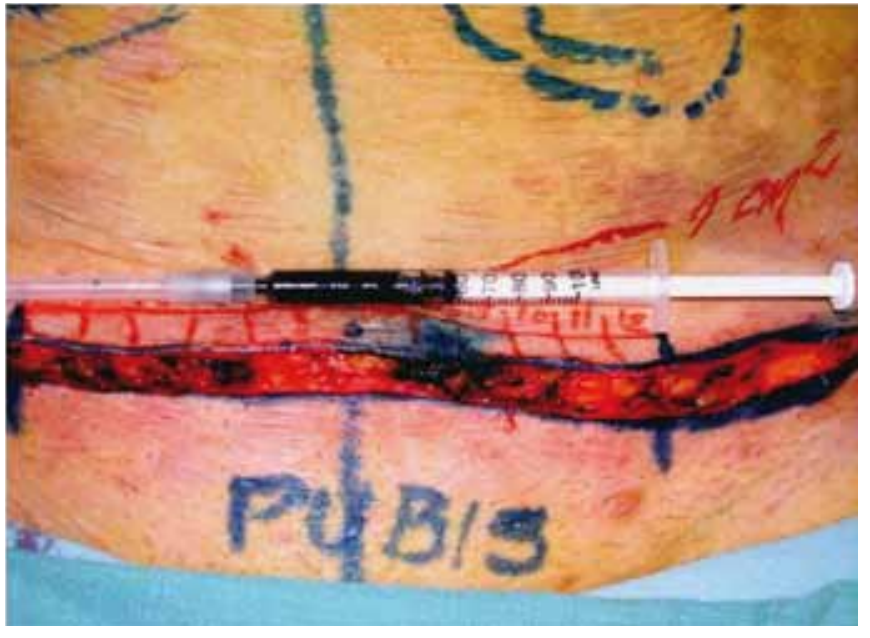

Figure 4 - Infiltration of methylene blue into the dermis to calculate the volume needed to cover $1 \mathrm{~cm}^{2}$ of skin surface.

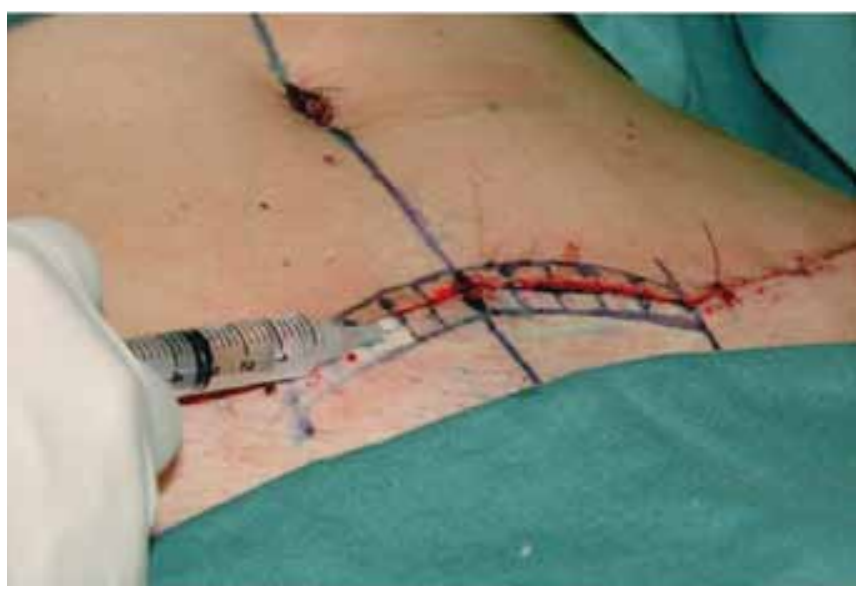

Figure 5 -Implantation of adult stem cells from adipose tissue into the dermis at $0.5 \mathrm{ml} / \mathrm{cm}^{2}$ of skin surface.

ranging from 1 to 10 . A score of 10 means the worst scar and the worst imaginable feeling. The sum of the scores in the observer's scale ranges from 5 to 50 , while the sum of the patient's scores ranges from 6 to 60 . The smallest sums of scores, 5 and 6 respectively, reflect normal skin. In this study, four observers, three physicians, and the operated patient herself assessed the healing results at 1 month, 3 months, 6 months, and 12 months postoperatively. Two plastic surgeons and one dermatologist, all with more than ten years of expertise and none from the medical staff of Hospital São Lucas, PUCRS, were included as observers.

2. Morphometric scale by digital photography and image analysis (Image Pro Plus, Media Cybermetics, United States $)^{37}$-photometric assessment performed by a physician of the Service of Plastic Surgery at Hospital
São Lucas of PUCRS who did not know in which side adult stem cells from adipose tissue were implanted. The scar was assessed by optical density of image (ODI) and average perpendicular length to the scar at ten points, on both sides, in the areas of implantation of the adult stem cells from adipose tissue and in areas of saline injection. The studied patients were photographed at all stages of assessment with the same camera (Sony ${ }^{\circledR}$ : DSC-W7, 7.2 mega pixels) at the same brightness and distance.

\section{Statistical Analysis}

All elements observed in the patients were quantified by pixel analysis of the photographs or by patients' impression and physicians' assessment scores. Average descriptive measures were obtained for each time of assessment. Then, the areas under the curve for the points formed by both sides of the scar to be compared were calculated. The curves were compared by Student's $t$ test for paired samples. Then, the proportions of favorable and unfavorable remarks on the intervention with stem cells were also compared using the binomial test. The adopted level of significance was alpha $=0.05$. Data were analyzed by intention to treat using the protocol Last Observation Carried Forward (LOCF), processed and assessed with SPSS, version 15.0.

\section{RESULTS}

Eighteen patients were operated on, 17 (94.4\%) of whom had excellent or good results, considering the surgical result; in one patient (5.5\%), the result was considered poor due to suture dehiscence in the suprapubic region. During the course of the study, another $5(27.7 \%)$ patients were lost to followup, leaving $12(66.6 \%)$ at the end of the study. However, the protocol of "intention to treat" was used to include all 18 patients in the analysis.

Using the criteria in the scale of Draaijers et al. ${ }^{36}$, it was possible to observe that the sides of the scars implanted with adult stem cells from adipose tissue showed better healing than those in which only saline solution was infiltrated (control) (Figures 6 and 7).

When the photometric aspects were compared, no statistically significant difference was detected in the random measurement $(\mathrm{P}=0.44)$ or total measuring $(\mathrm{P}=0.66)$ analyses.

To compare patients' assessments, six parameters were considered: pain, itching, color, stiffness, thickness, and irregularity. In the scores analysis, no statistical significance $(\mathrm{P}>0.17)$ was found for any of these aspects. However, consideration of all of the assessment events throughout the observation period yielded 42 measuring points, of which 15 were favorable to the control and 27 to the stem cells, 
reaching the significance level in favor of intervention by stem cells $(\mathrm{P}=0.12)$.

In the medical observers' assessments, five aspects were considered: vascularization, pigmentation, thickness,
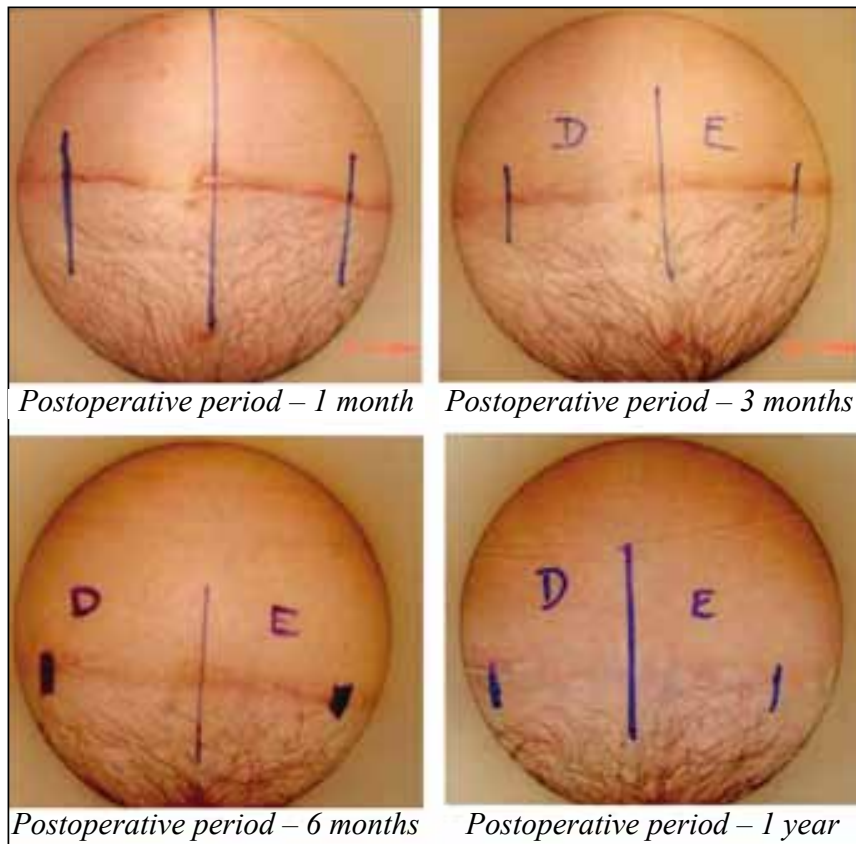

Figure 6 -Implantation of adult stem cells from adipose tissue on the right side.
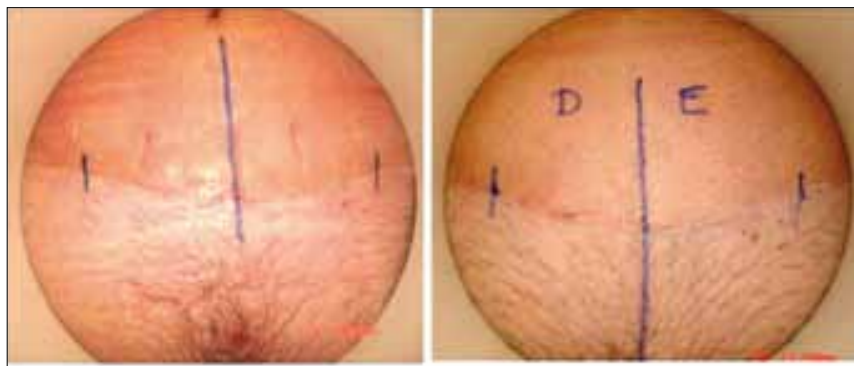

Postoperative period - 1 month
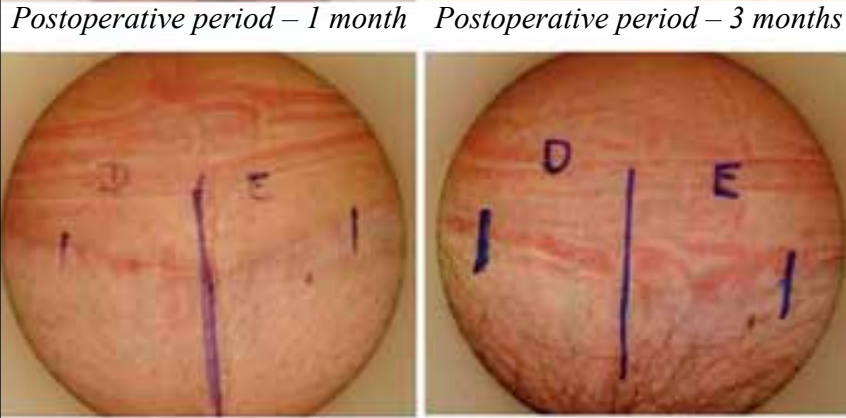

Postoperative period - 6 months

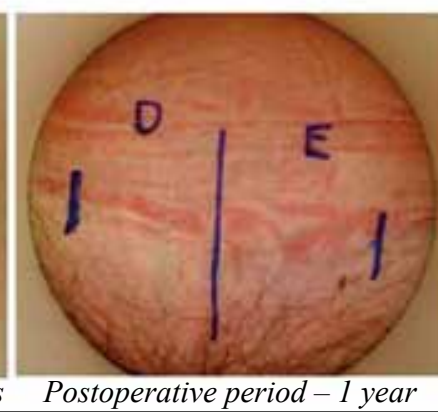

Figure 7 -Implantation of adult stem cells from adipose tissue on the left side. elasticity, and contraction. No statistically significant difference was found in any of these aspects $(P>0.37)$. However, consideration of all of the assessments distributed throughout the observation period yielded 35 measuring points, of which 8 were favorable to the control and 27 to the stem cells, reaching a significance level in favor of intervention by stem cells $(\mathrm{P}=0.003)$ (Figure 8$)$.

Stratifying the assessments by patients and photometry produced no statistically significant difference, probably due to the reduced number of events assessed. However, combining all assessments (physicians, patients and photometric) yielded a statistically significant difference in favor of the implantation of adult stem cells from adipose tissue. In a total of 91 events, 65 were favorable to the implantation with adult stem cells from adipose tissue and 26 to the control (P $<0.001$ ) (Table 1).

\section{DISCUSSION}

The abdominoplasty results are secondary to the focus of this research, which exclusively analyzes skin healing. However, they are important to prove that this clinical study did not cause any alterations that could compromise the postoperative healing process and outcomes in the patients participating.

Evidence-based practices ${ }^{38}$ are used to ensure good postsurgical healing results. In addition to accurate surgical technique and careful positioning of scars in accordance with the force lines of the skin, avoidance of any tension in the suture lines is also important. Immobilization and compression of the scar are recommended during the postoperative period, including the maturation phase ${ }^{3}$.

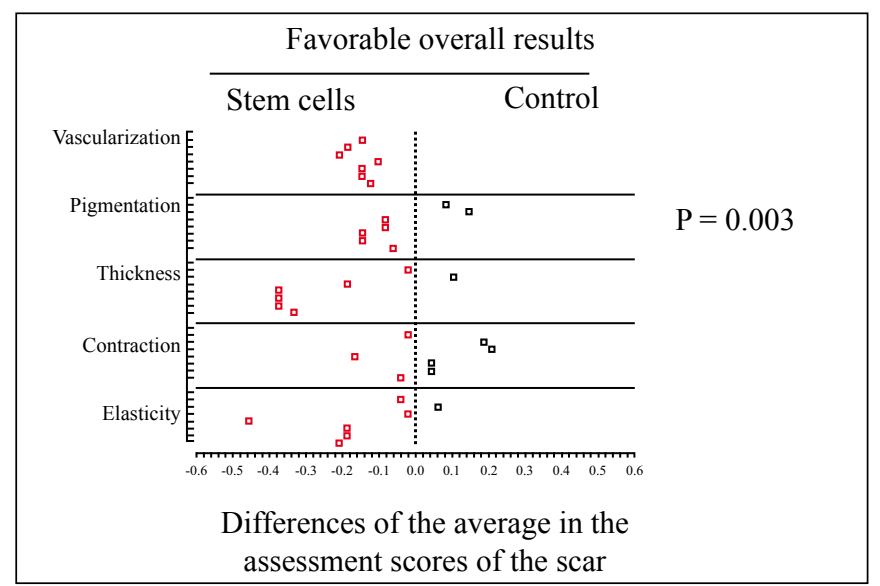

Figure 8 - Physicians' assessment. Graph with scattering of points representing the distribution of assessment events throughout the observation period and showing favorable overall results for the implantation of adult stem cells from adipose tissue $(P=0.003)$. 
Table 1 - Comparison of the assessment events during the observation period.

\begin{tabular}{l|c|c|c|c}
\hline Assessment method & Assessment events & \multicolumn{2}{|c|}{ Favorable to group } & P \\
\hline & & Stem cells & Control & \\
\hline Photometric & 14 & 11 & 3 & 0.106 \\
\hline Patients & 42 & 27 & 15 & 0.120 \\
\hline Physicians & 35 & 27 & 8 & 0.003 \\
\hline Total & 91 & 65 & 26 & $<0.001$ \\
\hline
\end{tabular}

Therapeutic measures such as use of corticosteroids, botulinum toxin, vitamins $\mathrm{A}$ and $\mathrm{E}$, silicone tapes and laser e radiotherapy are used for prevention or in the presence of hypertrophic scars or keloids ${ }^{3,8-11}$. This clinical, prospective, and randomized study was conducted with the same objective: the improvement of scars. The implantation of adult stem cells from adipose tissue into the dermis of the abdominoplasty surgical wound demonstrated a beneficial effect on healing. The autologous cells used had no contraindications and did not cause side effects, as may occur in other approaches that use corticosteroids or radiotherapy.

It was not possible to perform a comparative analysis with other similar clinical studies due to the scarcity of published research assessing the implantation of adult stem cells from adipose tissue into surgical incisions in human skin. The papers mentioned in this study had performed such analyses in laboratory animals $\mathrm{s}^{39,40}$, and their results, as in this research, also showed beneficial effects of cell therapy on skin healing.

As this is an initial study, the results reported here can be considered promising when compared to other studies of longer duration, such as experiments that employ cell therapy in the regeneration of other tissues. Studies on diseases or trauma of organs such as the heart, liver, kidney and peripheral nerves ${ }^{18,41-43}$ have proven that these tissues can be regenerated.

\section{CONCLUSION}

The effect of implanting adult stem cells from adipose tissue on skin healing of postoperative abdominoplasty wounds has proved to be satisfactory.

\section{REFERENCES}

1. Porter R. The greatest benefit to mankind: a medical history of humanity. New York: W. W. Norton \& Company; 1997.

2. Townsend Jr. CM, Beauchamp RD, Evers BM, Mattox KL. Sabiston textbook of surgery: the biological basis of modern surgical practice. $17^{\text {th }}$ ed. Philadelphia: Elsevier; 2004.

3. Lorenz HP, Longaker MT. Wound healing: repair biology and wound and scar treatment. In: Mathes SJ, ed. Plastic surgery. vol. 1. Philadelphia: Saunders Elsevier; 2006. p. 209-32.
4. Adzick NS, Longaker MT. Fetal wound healing. New York: Chapman \& Hall; 1992.

5. Lin RY, Sullivan KM, Argenta P, Peter Lorenz H, Scott Adzick N. Scarless human fetal skin repair is intrinsic to the fetal fibroblast and occurs in the absence of an inflammatory response. Wound Repair Regen. 1994;2(4):297-305.

6. Estes JM, Vande Berg JS, Adzick NS, MacGillivray TE, Desmoulière A, Gabbiani G. Phenotypic and functional features of myofibroblasts in sheep fetal wounds. Differentiation. 1994;56(3):173-81.

7. Bullard KM, Cass DL, Banda MJ, Adzick NS. Transforming growth factor beta-1 decreases interstitial collagenase in healing human fetal skin. Pediatr Surg. 1997;32(7):1023-7.

8. Xiao Z, Zhang F, Cui Z. Treatment of hypertrophic scars with intralesional botulinum toxin type A injections: a preliminary report. Aesthetic Plast Surg. 2009;33(3):409-12.

9. Horswell BB. Scar modification. Techniques for revision and camouflage. Atlas Oral Maxilofac Surg Clin North Am. 1998;6(2):55-72.

10. Viera MH, Amini S, Konda S, Berman B. Do postsurgical interventions optimize ultimate scar cosmesis. G Ital Dermatol Venereol. 2009;144(3):243-57.

11. Haedersdal M, Moreau KE, Beyer DM, Nymann P, Alsbjørn B. Fractional nonablative $1540 \mathrm{~nm}$ laser resurfacing for thermal burn scars: a randomized controlled trial. Lasers Surg Med. 2009;41(3):189-95.

12. Daley GQ, Goodell MA, Snyder EY. Realistic prospects for stem cell therapeutics. Hematology Am Soc Hematol Educ Program. 2003;398418.

13. Fodor WL. Tissue engineering and cell based therapies, from the bench to the clinic: the potential to replace, repair and regenerate. Reprod Biol Endocrinol. 2003;1:102.

14. Loeffler M, Bratke T, Paulus U, Li YQ, Potten CS. Clonality and life cycles of intestinal crypts explained by a state dependent stochastic model of epithelial stem organization. J Theor Biol. 1997;186(1):41-54.

15. Pittenger MF, Mackay AM, Beck SC, Jaiswal RK, Douglas R, Mosca JD, et al. Multilineage potential of adult human mesenchymal stem cells. Science. 1999;284(5411):143-7.

16. Tuan RS, Boland G, Tuli R. Adult mesenchymal stem cells and cellbased tissue engineering. Arthritis Res Ther. 2003;5(1):32-45.

17. Tohill M, Terenghi G. Stem-cell plasticity and therapy for injuries of the peripheral nervous system. Biotechnol Appl Biochem. 2004;40(Pt 1):17-24.

18. Braga-Silva J, Gehlen D, Padoin AV, Machado DC, Garicochea B, Costa da Costa J. Can local supply of bone marrow mononuclear cells improve the outcome from late tubular repair of human median and ulnar nerves? J Hand Surg Eur Vol. 2008;33(4):488-93.

19. Martinez-Estrada OM, Muñoz-Santos Y, Julve J, Reina M, Vilaró S. Human adipose tissue as a source of Flk-1+ cells: new method of differentiation and expansion. Cardiovasc Res. 2005;65(2):328-33.

20. Zuk PA, Zhu M, Mizumo H, Huang J, Futrell JW, Katz AJ, et al. Multilineage cells from human adipose tissue: implications for cell-based therapies. Tissue Eng. 2003;7(2):211-28.

21. De Ugarte DA, Morizono K, Elbarbary A, Alfonso Z, Zuk PA, Zhu M, et al. Comparison of multi-lineage cells from human adipose tissue and bone marrow. Cells Tissues Organs. 2003;174(3):101-9. 
22. Safford KM, Hicok KC, Safford SD, Halvorsen YD, Wilkison WO, Gimble JM, et al. Neurogenic differentiation of murine and human adipose-derived stromal cells. Biochem Biophys Res Commun. 2002;294(2):371-9.

23. Illouz YG. Anew method for localized lipodystrophies. Rev Chir Esthet. 1980;4:19.

24. Fournier P, Otteni FM. Lipodissection in body sculpturing: the dry procedure. Plast Reconstr Surg. 1983;72(5):598-609.

25. Fraser JK, Wulur I, Alfonso Z, Hedrick MH. Fat tissue: an underappreciated source of stem cells for biotechnology. Trends Biotechnol 2006;24(4):150-4.

26. Lambert APF, Zandonai AF, Bonatto D, Machado DC, Henriques JAP Differentiation of human adipose-derived adult stem cells into neuronal tissue: does it work? Differentiation. 2009;77(3):221-8.

27. Vasconez LO, De La Torre JI. Abdominoplasty. In: Mathes SJ, ed. Plastic surgery. Vol. 6. Philadelphia: Saunders Elsevier; 2006.

28. Pontes R. Abdominoplastia: ressecção em bloco e sua aplicação em lifting de coxa e torsoplastia. (Abdominoplasty: resection en bloc and its application in thigh lifting and torsoplasty) Rio de Janeiro: Revinter; 2004

29. Padoin AV, Braga-Silva J, Martins P, Rezende K, Rezende AR, Grechi $\mathrm{B}$, et al. Sources of processed lipoaspirate cells: influence of donor site on cell concentration. Plast Reconst Surg. 2008;122(2):614-8.

30. Morris DE, Wu L, Zhao LL, Bolton L, Roth SI, Ladin DA, et al. Acute and chronic animal models for excessive dermal scarring: quantitative studies. Plast Reconstr Surg. 1997;100(3):674-81.

31. Sullivan T, Smith J, Kermode J, McIver E, Courtemanche DJ. Rating the burn scar. J Burn Care Rehabil. 1990;11(3):256-60.

32. Baryza MJ, Baryza GA. The Vancouver Scar Scale: an administration tool and its interrater reliability. J Burn Care Rehabil. 1995;16(5):535-8.

33. Nedelec B, Shankowsky HA, Tredgett EE. Rating the resolving hypertrophic scar: comparison of the Vancouver Scar Scale and scar volume. J Burn Care Rehabil. 2000;21(3):205-12.
34. Mustoe TA, Cooter RD, Gold MH, Hobbs FD, RameletAA, Shakespeare $\mathrm{PG}$, et al. International clinical recommendations on scar management. Plast Reconstr Surg. 2002;110(2):560-71.

35. Beausang E, Floyd H, Dunn KW, Orton CI, Ferguson MW. A new quantitative scale for clinical scar assessment. Plast Reconstr Surg. 1998;102(6):1954-61.

36. Draaijers LJ,Tempelman FR, Botman YA, TuinebreijerWE, Middelkoop E, Kreis RW, et al. The patient and observer scar assessment scale: a reliable and feasible tool for scar evaluation. Plast Reconstr Surg. 2004;113(7):1960-5

37. Davey RB, Sprod RT, Neild TO. Computerised colour: a technique for the assessment of burn scar hypertrophy. A preliminary report. Burns. 1999;25(3):207-13

38. Atiyeh BS. Nonsurgical management of hypertrophic scars: evidence-based therapies, standard practices, and emerging methods. Aesthetic Plast Surg. 2007;31(5):468-92.

39. StoffA, Rivera AA, Sanjib Banerjee N, Moore ST, Michael Numnum T, Espinosa-de-Los-Monteros A, et al. Promotion of incisional wound repair by human mesenchymal stem cell transplantation. Exp Dermatol. 2009;18(4):362-9.

40. Saton H, Kishi K, Tanaka Y, Kubota Y, Nakajima T, Akasaka Y, et al. Transplanted mesenchymal stem cells are effective for skin regeneration in acute cutaneous wounds. Cell Transplant. 2004;13(4):405-12.

41. Mays RW, van't Hof W, Ting AE, Perry R, Deans R. Development of adult pluripotent stem cell therapies for ischemic injury and disease. Expert Opin Biol Ther. 2007;7(2):173-84.

42. Navarro-Alvarez N, Soto-Gutierrez A, Kobayashi N. Stem cell research and therapy for liver disease. Curr Stem Cell Res Ther. 2009;4(2):141-6.

43. Watorek E, Klinger M. Stem cells in nephrology: present status and future. Arch Immunol Ther Exp (Warsz). 2006;54(1):45-50.

\section{Correspondence to:}

Pedro Djacir Escobar Martins

Av. Engenheiro Alfredo Correa Daudt, 125 - ap. 301 - Boa Vista - Porto Alegre, RS, Brazil - CEP 90480-120

E-mail: clinicapedromartins@terra.com.br 